\title{
Genetic reduction of lipoic acid synthase expression modestly increases atherosclerosis in male, but not in female, apolipoprotein E deficient mice
}

\author{
Xianwen $\mathrm{Yi}^{*}$, Longquan Xu, Kuikwon Kim, Hyung-Suk Kim, and Nobuyo Maeda \\ Department of Pathology and Laboratory Medicine, University of North Carolina at Chapel Hill, \\ NC 27599-7525, USA
}

\begin{abstract}
Objectives-To evaluate the effects of a genetic reduction of Lias gene expression on atherosclerosis development.
\end{abstract}

Methods and Results-Heterozygous knockout mice for the lipoid acid synthase gene $\left(\right.$ Lias $\left.^{+/-}\right)$were crossed with apolipoprotein E-deficient $\left(\mathrm{ApoE}^{-/-}\right)$mice, and the plaque size in aortic sinuses of $\mathrm{Lias}^{+/-} \mathrm{ApoE}^{-/-}$mice was evaluated at 6 months of age. Lesions at the aortic sinus in Lias $^{+/-} \mathrm{ApoE}^{-/-}$males were significantly larger (1.5X) than those in $\mathrm{Lias}^{+/+} \mathrm{ApoE}^{-/-}$ littermate males. The lesion size was inversely correlated with an increased erythrocyte reduced glutathione/ oxidized glutathione (GSH/GSSH) ratio, an systemic index of body redox balance. $\mathrm{Lias}^{+/-} \mathrm{ApoE}^{-1-}$ males also had significantly increased plasma cholesterol and reduced pyruvate dehydrogenase complex activity in the liver. Significant reductions in the expression of genes for antioxidant enzymes, including superoxide dismutase 1 (SOD1) and SOD2, were observed in aortas of $\mathrm{Lias}^{+/-} \mathrm{ApoE}^{-/-}$males. Female $\mathrm{Lias}^{+/-} \mathrm{ApoE}^{-/-}$also exhibited changes in these parameters, parallel to those observed in males. However, the Lias gene effects for the majority of these factors, including atherosclerotic lesion size, were not significant in females.

Conclusions-Our data provide evidence that Lias deficiency enhances atherosclerosis in male mice, at least in part due to reduce antioxidant capacity. The notable absence of such effects in females leaves open the possibility of a gender-specific protection mechanism.

\section{Keywords}

antioxidant; lipoic acid; Lias mouse model; atherosclerosis; apolipoprotein E null mice

\section{Introduction}

It is evident that oxidative stress, an imbalance between free radical production and antioxidant defense, plays an important role in the development of atherosclerosis [1].

\footnotetext{
(C) 2010 Elsevier Ireland Ltd. All rights reserved.

Correspondence to: Dr. Xianwen Yi, Department of Pathology and Laboratory Medicine, University of North Carolina at Chapel Hill, 701 Brinkhous-Bullitt Building, Chapel Hill, NC 27599-7525, Phone: 919-966-6912, Fax: 919-966-8800, xyi2000@ med.unc.edu.

Publisher's Disclaimer: This is a PDF file of an unedited manuscript that has been accepted for publication. As a service to our customers we are providing this early version of the manuscript. The manuscript will undergo copyediting, typesetting, and review of the resulting proof before it is published in its final citable form. Please note that during the production process errors may be discovered which could affect the content, and all legal disclaimers that apply to the journal pertain.

Conflict of interest statement

The authors have no conflict of interest.
} 
Alpha-lipoic acid (1, 2-dithiolane-3-pentanoic acid, thioctic acid, LA) is a potent sulfurcontaining antioxidant [2]. It is also a cofactor for mitochondrial enzymes such as pyruvate dehydrogenase complex (PDC) and alpha keto-glutarate dehydrogenase complex (KDC), both of which participate in glucose metabolism and ATP generation [3]. The presence of LA in the diet has antioxidant, anti-inflammatory and lipid-decreasing effects, all of which are known to act as deterrents against atherosclerosis in animal models [4-6]. However, results in the literature are somewhat conflicting with some studies suggesting that LA also exhibits pro-oxidant properties [7]. Controversy also persists with regards to plasma cholesterol, with one set of work suggesting LA acts to reduce the sterol [5,8,9], while another set reports the absence of any such effect $[4,10]$. Such discrepancies may stem from differing routes of LA administration as well as other pharmacokinetic and pharmaceutical factors. While LA is a chiral compound with two enantiomers, only R-(+)-lipoic acid can operate as an enzymatic cofactor. This suggests that pure R-(+)-lipoic acid may possess different pharmaceutical properties compared to those of a racemic mixture. Obviously, using a genetic model can reduce or avoid extraneous influences such as choice of administrative route and chirality issues in exogenous LA.

Endogenous production of LA is mediated by lipoic acid synthase (Lias) in mitochondria. The Lias homozygous knockout mice die in utero shortly after implantation, suggesting endogenous LA is essential for normal embryo development [11]. Supplementation of exogenous racemic LA to Lias $^{+/-}$dams did not rescue embryonic Lias $^{-1-}$ embryos [11]. The Lias gene expression in many organs of $\mathrm{Lias}^{+/-}$mice is half of that in their wild-type littermates. Although $\mathrm{Lias}^{+/-}$mice appear normal and healthy, the reactive oxygen species (ROS) level is significantly increased compared to $\mathrm{Lias}^{+/+}$littermates under stress conditions, such as lipopolysaccharide-induced sepsis [12]. These studies clearly indicate that endogenous antioxidant capacity in $\mathrm{Lias}^{+/-}$mice is reduced.

In this study, we mated $\mathrm{Lias}^{+-}$mice with $\mathrm{ApoE}^{-/-}$mice to test whether the mice with 50\% normal expression of the Lias gene would increase oxidative stress and lead to more severe atherosclerosis. Our results showed that the mean areas of aortic plaques in the male Lias $^{+/-} \mathrm{ApoE}^{-/-}$mice were significantly larger than those in male $\mathrm{Lias}^{+/+} \mathrm{ApoE}^{-/-}$ littermates. The larger plaque sizes were accompanied by enhanced oxidative stress, increased plasma cholesterol, and a transition from glucose to lipid catabolism in the liver. The majority of parameter trends in the $\mathrm{Lias}^{+/-} \mathrm{ApoE}^{-/-}$females, including atherosclerotic plaque size, were not statistically different from those in the Lias $^{+/+} A_{p o E^{-/-}}$females, although they did exhibit trends in the same direction as the males.

\section{Methods}

\subsection{Animals}

ApoE ${ }^{-/-}$mice on 129/SvEv genetic background [13] were crossed with $\mathrm{Lias}^{+/-}$mice on the same background [11] to generate the double mutant mice. Both male and female Lias $^{+/-} \mathrm{ApoE}^{-1-}$ mice were employed for our experiments and their littermates Lias $^{+/+}$ApoE $^{-/-}$mice served as controls. Mice were fed normal chow, and were given free access to water. Mouse experiments were carried out under protocols approved by the Institutional Animal Care and Use Committee of the University of North Carolina at Chapel Hill.

\subsection{Atherosclerotic Lesion Analysis}

Atherosclerotic lesion analyses followed the standard protocol in our laboratory [14]. Frozen sections of the proximal aorta were stained with Sudan IV and counterstained with hematoxylin, and the areas of atherosclerotic lesions were measured using NIH 1.59 
Imaging Software. The average lesion area in sections from four anatomically defined positions was taken as the lesion size of each animal.

\subsection{Biochemical Analysis}

2.3.1. Plasma parameters-Mice were fasted for 4 hours and then blood samples were collected from the orbital sinus. Plasma levels of glucose, total cholesterol and triglyceride (TG) were measured with commercially available kits (Wako, Richmond, VA). Plasma pyruvate concentrations were examined using the assay kit (BioVision, Inc. Mountain View, CA). Lactic acid concentrations in tissues were determined as described [15].

2.3.2. Lipoprotein profile-Plasma lipoprotein profiles were determined by fast performance liquid chromatography (FPLC) chromatography (Amersham Pharmacia Biotech, Piscataway, NJ), followed by measurement of cholesterol content in each fraction [14].

2.3.3. Biomarkers of oxidative stress-The redox state of the whole body was determined as the ratio of reduced glutathione (GSH)/oxidized glutathione (GSSG) in erythrocytes using an assay kit (Calbiochem, San Diego, CA). Plasma lipid peroxide content was determined using the thiobarbituric acid reactive substances (TBARS) assay with malondialdehyde as the standard [11].

\subsection{Real-time reverse-transcription polymerase chain reaction}

Thoracic aortas (including arch, ascending and descending aorta), and livers were dissected from 6 month old mice and total RNAs were isolated using an ABI 6700 Automated Nucleic Acid Workstation following the manufacturer's protocol (Applied Biosystems, Foster City, CA). Expression of the genes for Lias, copper/zinc superoxide dismutase (Sod1), manganese superoxide dismutase (Sod2), and glutathione peroxidase $1(G P x 1)$ in the aortas, as well as pyruvate dehydrogenase phosphatase 2 ( $P d p 2)$, pyruvate dehydrogenase kinase 3 (Pdk3) and peroxisome proliferator-activated receptor gamma $(P P A R-g)$, hydroxymethylglutarylcoenzyme A reductase (HMG-CoA reductase), cholesterol 7 alpha hydroxylase (CYP7 $\alpha$ ), low density lipoprotein receptor (LDLR) and carnitine palmitoyltransferase I $\alpha(\mathrm{Cpt} 1 \alpha)$ in the livers, were determined by quantitative real-time RT-PCR with $\beta$-actin as the reference gene in each reaction.

\subsection{Isolation of mitochondria}

Mitochondria from the liver were isolated as previously described [17] with minor modifications. Briefly, the liver was excised, minced and homogenized in isolation buffer consisting of $100 \mathrm{mM}$ Tris/HCl, pH 7.4, $2 \mathrm{mM}$ EDTA, $210 \mathrm{mM}$ mannitol, $70 \mathrm{mM}$ sucrose and $2 \mathrm{mM}$ dithiothreitol. The homogenate was centrifuged at $600 \times \mathrm{g}, 10 \mathrm{~min}$, at $4{ }^{\circ} \mathrm{C}$. The supernatant was centrifuged at $7,000 \times \mathrm{g}$ for $10 \mathrm{~min}$, at $4^{\circ} \mathrm{C}$. Mitochondria were washed twice by re-suspension and centrifugation at $7,000 \times \mathrm{g}$ for $10 \mathrm{~min}$, at $4{ }^{\circ} \mathrm{C}$. Following the final centrifugation, mitochondria were re-suspended in the isolation buffer with protease inhibitor cocktail (Sigma, St. Louis). Concentrations of mitochondria were determined by BCA protein assay kit (Thermo Scientific, Rockford, IL) and bovine serum albumin as the standard.

\subsection{Measurement of pyruvate dehydrogenase complex activity}

PDC activity was determined in mitochondria isolated from the liver using a PDC Assay Kit (MitoSciences, Eugene, Oregon) following the manufacture's instruction. 


\subsection{Measurement of apoptosis in aorta plaque}

Cell apoptosis in the plaques was examined using TUNEL ApopTag Fluorescein in Situ Apoptosis Detection Kit (Chemicon International Inc. Billerica, Massachusetts). Freshly cut cryosections were fixed with $1 \%$ paraformaldehyde in PBS (pH 7.4) for 10 minutes at room temperature, rinsed with PBS and permeabilized with a mixture 2:1 of ethanol and acetic acid for 5 minutes at $-20^{\circ} \mathrm{C}$. Slides were incubated with the reaction buffer containing the TdT enzyme for 1 hour at $37^{\circ} \mathrm{C}$ in a humidified chamber and then incubated with a FITCconjugated anti-digoxigenin antibody for 30 minutes at room temperature. Finally, slides were mounted with a DAPI/antifade medium. Slides were observed and photographed with an Olympus BX61 fluorescence microscope (Olympus, Center Valley, PA).

\subsection{Statistics}

All values are expressed as mean \pm S.E. Statistical analysis was carried out using JMP software (SAS, Cary, NC). Effects of antioxidant status and plasma cholesterol on the lesion sizes in $\mathrm{Lias}^{+/-} \mathrm{ApoE}^{-/-}$and $\mathrm{Lias}^{+/+} \mathrm{ApoE}^{-/-}$mice were analyzed by linear regression.

\section{Results}

\subsection{Increased body weight in $\mathrm{Lias}^{+/-} \mathrm{ApoE}^{-/-}$Mice}

All animals gained weight steadily during the study period. At 6 months, male Lias $^{+/-}$ ApoE ${ }^{-1-}$ mice were heavier than male Lias $^{+/+} \mathrm{ApoE}^{-/-}$mice by $7.3 \%(P<0.01)$. Their food intake did not differ. Female $\mathrm{Lias}^{+-} \mathrm{ApoE}^{-/-}$mice were also heavier but the difference was not statistically significant (Table 1 ).

\subsection{Male, but not female, Lias $^{+/-}$ApoE $^{-1-}$ mice had larger lesions}

Atherosclerotic plaques at the aortic sinus of each mouse were histologically analyzed at 6 months of age. Male Lias $^{+-}$apoE $^{-1-}$ mice had a $43 \%$ increase in atherosclerotic plaque area compared to male Lias $^{+/+}$apoE $^{-/-}$mice $(P<0.001)$ (Figure 1E). The mean size of lesions at the aortic sinus was $9.3 \pm 0.8 \mu \mathrm{m}^{2} \times 10^{4}$ and $6.4 \pm 0.6 \mu \mathrm{m}^{2} \times 10^{4}(P<0.05)$ in 6-month-old Lias $^{+/-}$apoE $^{-/-}$and ias $^{+/+}$apoE $^{-/-}$males, respectively. In contrast, increases in lesion size in females were small with no significant difference between the two genotypes. The mean lesion size at the aortic sinus was $7.7 \pm 0.5 \mu \mathrm{m}^{2} \times 10^{4}$, and $7.3 \pm 0.7 \mu \mathrm{m}^{2} \times 10^{4}$ in $\mathrm{Lias}^{+/-} \mathrm{apoE}^{-/-}$ and $\mathrm{Lias}^{+/+}$apoE $^{-/-}$females respectively (Figure 1E). However, when both males and females were analyzed together using two-way ANOVA, the genotype effect was significant ( $P<0.05$ for genotype effect, $P=0.47$ for gender effect, and $P=0.54$ for the interaction). Plaques in all animals were mature and complex, with fibrous caps, cholesterol clefts and necrotic lipid cores (Figure 1A through 1D). Apoptotic cells were not detected in the plaques in the aortic sinus of the 6 month old Lias $^{+/-} \mathrm{ApoE}^{-/-}$or Lias $^{+/+} \mathrm{ApoE}^{-/-}$males.

\subsection{Increased plasma cholesterol in $\mathrm{Lias}^{+/-} \mathrm{apoE}^{-/-}$mice}

At the end of the observed period, total plasma cholesterol levels were significantly higher in male $\mathrm{Lias}^{+/} \mathrm{apoE}^{-/-}$than in male $\mathrm{Lias}^{+/+} \mathrm{apoE}^{-/-}$mice $(P<0.05)$. Plasma cholesterol levels in female $\mathrm{Lias}^{+/-} \mathrm{apoE}^{-/-}$mice were also higher than $\mathrm{Lias}^{+/-} \mathrm{apoE}^{-/-}$mice, but the difference was not statistically significant. Nevertheless, when both genders were analyzed together by two-way ANOVA, the 50\% reduction in Lias gene expression associated with the Lias $^{+/-} \mathrm{ApoE}^{-/-}$mice increased plasma cholesterol $(P<0.01$ for the genotype effect, $P=$ NS for gender effect, and for interaction of these two factors) (Table 1). However, there was no correlation between plasma cholesterol and the atherosclerotic lesion size in the individual animals (Figure 2E and 2F). Plasma lipoprotein profile analysis by FPLC showed that the increased plasma cholesterol in $\mathrm{Lias}^{+/-} \mathrm{apoE}^{-/-}$mice was distributed primarily in Very Low Density Lipoprotein (VLDL) and Intermediate Density Lipoprotein (IDL) 
fractions in both males and females (Figure 2A and 2B). The effect of LA on plasma TG was not different between the two groups ( $P=0.08$ for effect of genotype effect, $P=0.1$ for gender effect, and $P=0.9$ for interaction) (Table 1 ).

\subsection{Increased oxidative stress in Lias $^{+/-} \mathrm{ApoE}^{-/-}$mice}

The systemic redox status of the whole body was estimated by determining the ratio of GSH/GSSG in erythrocytes. The ratio of GSH/GSSG in $\mathrm{Lias}^{+/-} \mathrm{ApoE}^{-/-}$mice was significantly lower $(P<0.05)$ in males (Figure $2 \mathrm{C}$ ). The females showed the same trend of reduction but the difference was not significant. A two-way ANOVA showed that the Lias genotype effect was significant $(P<0.05)$. Likewise, levels of plasma TBARS in both male and female $\mathrm{Lias}^{+/-} \mathrm{ApoE}^{-/-}$mice were elevated compared to $\mathrm{Lias}^{+/+} \mathrm{ApoE}^{-/-}$mice, but only the male mice showed statistical significance (Figure 2D). Again, the amount of TBARS was significantly affected by the genotype when the data from both genders were processed together by two-way ANOVA $(P<0.01$ for genotype effect, $P=\mathrm{NS}$ for gender effect and for interaction). Linear regression analysis showed that the ratio of GSH/GSSG was inversely correlated with atherosclerotic lesion size in individual male mice but not in female mice (Figure $2 \mathrm{G}$ and $2 \mathrm{H}$ ).

\subsection{Altered hepatic metabolism in the $\mathrm{Lias}^{+/-} \mathrm{ApoE}^{-1-}$ mice}

The activity of PDC in male and female $\mathrm{Lias}^{+/-} \mathrm{ApoE}^{-/-}$livers was $45 \%$ and $55 \%$, respectively, of those in their WT counterparts (10.1 vs 21.4 and $11.0 \mathrm{vs} 20.0 \mathrm{U} / \mathrm{mg}$ protein, Figure 3A). Plasma pyruvate levels in $\mathrm{Lias}^{+-} \mathrm{ApoE}^{-/-}$mice were elevated by about $50 \%$ in both genders (Table 1). Plasma lactate concentrations were not significantly different between the two genotypes (data not shown). To determine whether the $\mathrm{Lias}^{+/-}$mutation exerts a regulatory effect on the pyruvate dehydrogenase complex, gene expression of $P d p 2$, $P d k 3$ and Pparg was measured in the liver. The results showed no genotype difference in the expression of these genes (Supplemental Table 1B).

Expression of the genes for HMG-CoA reductase and Cyp7 $\alpha$ did not differ significantly between the Lias $^{+/}$apoE $^{-/-}$mice and their control counterparts (Supplemental Table 1B). However, the expression of the $L d l r$ gene was slightly lower $(P=0.07)$ in the $\mathrm{Lias}^{+/-}$apoE $^{-/-}$ mice than in the $\mathrm{Lias}^{+/+} \mathrm{apoE}^{-/-}$mice, suggesting that the increase in plasma cholesterol might be due to decreased uptake of lipoproteins by the liver. Finally, liver gene expression of Cptla was significantly increased by $44 \%$ in Lias $^{+/} \mathrm{ApoE}^{-1-}$ mice compared with Lias+l + ApoE-/- mice (Figure 3B).

\subsection{Reduced aortic expression of antioxidant enzymes in Lias $^{+/-}$ApoE $^{-1-}$ males}

To determine whether Lias deficiency in $\mathrm{Lias}^{+/-} \mathrm{ApoE}^{-/-}$mice influences antioxidant capacity in the aorta, the expression of genes coding for Lias, Sod1, Sod2 and Gpx-1 was assessed. Male $\mathrm{Lias}^{+/-} \mathrm{ApoE}^{-/-}$aorta showed significantly reduced gene expression of Sodl and Sod2 (43\% and 60\%, respectively), compared with $\mathrm{Lias}^{+/+} \mathrm{ApoE}^{-/-}$aorta (Figure 3C, 3D). Gpx-1 gene expression in $\mathrm{Lias}^{+-} \mathrm{ApoE}^{-/-}$was also lower but the difference did not reach statistical significance. The gene expression of interleukin-6 (IL-6), a proinflammatory cytokine, increased 2.4-fold in male $\mathrm{Lias}^{+-} \mathrm{ApoE}^{-/-}$mice and 1.7-fold in female $\mathrm{Lias}^{+/+} \mathrm{ApoE}^{-/-}$mice, but the difference was not statistically significant in either sex $(P=0.11$ by ANOVA, Supplemental Table $1 \mathrm{~A})$.

\section{Discussion}

The present study showed that atherosclerotic plaques in male $A p o E^{-/-}$mice with $50 \%$ normal expression of the Lias gene were modestly, but significantly, larger than those in ApoE $E^{-/-}$males with the wild type Lias gene. Our genetic model provides evidence for the 
role of endogenous LA in metabolic regulation, cholesterol-lowering and as an antioxidant and anti-atherogenic molecule. The anti-atherogenic effect of endogenous LA was accompanied by increased whole body oxidative stress, and reduced expression of genes for antioxidant enzymes SOD1 and SOD2 in the aorta. This phenomenon may also involve LA's anti-inflammatory properties and its regulatory influences over glucose metabolism, as indicated by increased gene expression of the pro-inflammatory cytokine, IL-6, increased body weight, and decreased PDC activity in the $\mathrm{Lias}^{+/} \mathrm{ApoE}^{-1-}$ mice.

Under normal physiological conditions, excess ROS in the aorta are mainly scavenged by antioxidant enzymes such as SOD and peroxidase. Increased levels of ROS, including superoxide and hydrogen peroxide have been reported in atherosclerotic vessel walls [18]. We were concerned whether the mice with 50\% normal expression of the Lias gene would lead to a diminished endogenous antioxidant defense reservoir, as LA is a powerful antioxidant in addition to being capable of recycling other antioxidants [19]. Since decreasing mRNA levels usually indicate a decline in production of a protein/enzyme, we examined antioxidant enzyme gene expression in the whole aorta to evaluate local antioxidant capacity. We found that $\operatorname{Sod} 1$ and $\operatorname{Sod} 2 \mathrm{mRNA}$ levels were significantly decreased in the aorta of $\mathrm{Lias}^{+/-} \mathrm{ApoE}^{-/-}$male mice, compared to those of $\mathrm{Lias}^{+/+} \mathrm{ApoE}^{-/-}$ mice. The causative relationships between the reduced Sodl/Sod2 expression and atherosclerosis, however, are far from simple. For instance, Heon et al. reported that the mRNA levels of many antioxidant enzyme genes, including SodI and Sod2, in late stages of atherosclerosis were reduced as the animals aged and plaque size increased [20]. They also showed that in the period preceding visible lesion formation, mRNA levels of the antioxidant enzymes in the aortic arch of $A p o E^{-/-}$mice were higher than those in agematched wild-type mice [20]. Thus, the decreased Sodl and Sod2 expression in the aortas of Lias $^{+/-} \mathrm{ApoE}^{-/-}$mice could be due to increased plaque development. However, we found no correlation between the expression levels of these genes and plaque sizes in individual animals. Instead, we observed that the ratio of GSH/GSSG in erythrocytes, an index of total body antioxidant capacity, was markedly reduced in male $\mathrm{Lias}^{+/-} \mathrm{ApoE}^{-/-}$mice and its reduction was inversely correlated with aortic lesion size in individual animals. Taken together, these observations strongly suggest that oxidative stress is one of the mechanisms underlying the increased atherosclerosis in the male $\mathrm{Lias}^{+-} \mathrm{ApoE}^{-/-}$mice.

Increased plasma cholesterol is known to be a major risk factor related to the development of atherosclerosis [21]. However, the effect of exogenous LA on plasma cholesterol levels in animal models has produced conflicting data $[4,5,8-10]$. Plasma cholesterol levels are significantly higher in $\mathrm{Lias}^{+/-} \mathrm{ApoE}^{-/-}$mice than $\mathrm{Lias}^{+/+} \mathrm{ApoE}^{-/-}$mice, although linear regression analysis indicates that a high plasma cholesterol level is not a major contributing factor to atherosclerosis development in our animals. To explore the mechanism whereby LA influences plasma cholesterol, we examined changes in gene expression relevant to cholesterol metabolism. The gene expression of HMG-CoA reductase, the rate limiting step for cholesterol synthesis; CYP7 $\alpha$, the first rate-limiting step of bile acid synthesis from cholesterol, did not vary considerably between $\mathrm{Lias}^{+/-} \mathrm{ApoE}^{-/-}$mice and $\mathrm{Lias}^{+/+} \mathrm{ApoE}^{-/-}$ mice. However, gene expression for LDLR in $\mathrm{Lias}^{+/-} \mathrm{ApoE}^{-/-}$mice was slightly reduced, suggesting that reduced lipoprotein uptake might at least in part contribute to the increased plasma cholesterol levels in Lias $^{+-}{ }^{-1}$ poE $^{-1-}$ mice. Another plausible mechanism is that LA suppresses appetite [22], resulting in reduced dietary intake of cholesterol. Although food intake was not significantly different, $\mathrm{Lias}^{+/-} \mathrm{ApoE}^{-/-}$mice gained more weight. This is consistent with the body weight reducing effects of exogenous LA [16,22]. Thus, this effect, combined with the overall change in metabolic state, may contribute to the plasma cholesterol increase in the presence of Lias deficiency. Like the reports regarding the effects of LA on plasma cholesterol levels, reports of its effect on plasma triglyceride (TG) are also conflicting [4]. These differences could depend on the chiralic nature of LA, dose, diet and/ 
or other unknown factors. The differences could also come from distinct functions between endogenous and exogenous LA in metabolic pathways, such as increased fatty acid oxidation.

Our data also indicate that LA may participate in regulating an interaction between oxidative stress and PDC activity. PDC works as a critical link between glycolysis and the Krebs cycle, catalyzing the oxidative decarboxylation of pyruvate to form acetyl CoA as part of aerobic glucose metabolism. The strict cofactor requirements and stringent regulation of PDC make it vulnerable during diseases [23]. PDC is known to be targeted and even inactivated by ROS, and one PDC subunit, dihydrolipoyl transacetylase (E2) (where lipoic acid covalently binds), is particularly susceptible to impairment [3]. Since exogenous LA is synthesized by Lias from octanoic acid moiety attached to subunits E2 of PDC as substrates, exogenous LA may not be incorporated into the apoenzyme [11]. Nevertheless, even if exogenous LA does not directly function as a cofactor of mitochondrial enzymes, a substantial reduction of oxidative stress likely facilitates overall cellular metabolism. The PDC complex is regulated by phosphoryl covalent modification, being inactivated by PDH kinase and activated by PDH phophatase. However, our data from the gene expression analysis of $P d p 2$ and $P d k 3$ exclude the possibility that the decline in PDC activity is regulated by LA through altered synthesis of the two modifying enzymes. Reduced PDC activity in the $\mathrm{Lias}^{+/-} \mathrm{ApoE}^{-/-}$mice most likely, therefore, is the direct consequence of Lias deficiency in the mitochondria. Increased Cptla gene expression in $\mathrm{Lias}^{+/-} \mathrm{ApoE}^{-/-}$livers suggests a compensatory increase in the usage of fatty acids as an energy source. These metabolic changes, combined with a decrease in antioxidant capacity, could lead to mitochondrial damage which has been thought to associate with development of atherosclerotic plaques. Further investigation will be necessary to determine whether a 50\% reduction in Lias expression is sufficient to cause mitochondrial dysfunction in cells such as macrophages, smooth muscle cells and endothelial cells, and can contribute to the development of atherosclerosis. We also note that pyruvate can function as an antioxidant and reduce lipid peroxide to lipid hydroxide [24]. However, increased plasma pyruvate was not sufficient to overcome the deficiency in overall antioxidant capacity in the Lias $^{+/-} \mathrm{ApoE}^{-1-}$ mice.

One important finding of our experiments is that a significant increase the severity of atherosclerosis was not detected in female mice. Interestingly, all the differences observed in males were also present in females, although the differences were less significant or not significant. Thus, the effect of a 50\% reduction in Lias gene expression appears to be dampened in females compared to males. This suggests the presence of a female-specific protection mechanism against the consequences of reduced LA. The basis for this gender difference is not fully understood, but recent clinical and experimental data suggest that levels of vascular ROS during normal physiological conditions may be lower in females than males [25]. Reduced production of ROS may mask the genotype effects of LA in females. It is also possible that sex hormones such as estrogen enhance the normal antioxidant capacity in females. The gender difference in oxidative stress and antioxidant activities could, therefore, account for the non-significance in the atherosclerotic plaque size we observed in female $\mathrm{Lias}^{+/-} \mathrm{ApoE}^{-/-}$compared to $\mathrm{Lias}^{+/+} \mathrm{ApoE}^{-/-}$mice.

In conclusion, our genetic model provides evidence that a reduction in endogenous lipoic acid modestly increases atherosclerosis in atherosclerosis-prone male mice, and this acceleration was strongly correlated with a reduction in the antioxidant capacity.

\section{Supplementary Material}

Refer to Web version on PubMed Central for supplementary material. 


\section{Acknowledgments}

We thank Shinja Kim and Dr. Jose Arbones-Mainar for technical help and Lance Johnson, Sylvia Hiller and Benjamin Bleasdale for critical reading of the manuscript. This work was supported by NIH grants, HL042630 and HL087946.

\section{References}

1. Steinberg D, Witztum JL. Is the oxidative modification hypothesis relevant to human atherosclerosis? do the antioxidant trials conducted to date refute the hypothesis. Circulation 2002;105(17):2107-2111. [PubMed: 11980692]

2. Biewenga GP, Haenen GR, Bast A. The pharmacology of the antioxidant lipoic acid. Gen Pharmacol 1997;29:315-331. [PubMed: 9378235]

3. Reed LJ. From lipoic acid to multi-enzyme complexes. Protein Sci 1998;7:220-224. [PubMed: 9514279]

4. Zhang WJ, Bird KE, McMillen TS, LeBoeuf RC, Hagen TM, Frei B. Dietary alpha-lipoic acid supplementation inhibits atherosclerotic lesion development in apolipoprotein E-deficient and apolipoprotein E/low-density lipoprotein receptor-deficient mice. Circulation 2008;117:421-428. [PubMed: 18158360]

5. Amom Z, Zakaria Z, Mohamed J, et al. Lipid lowering effect of antioxidant alpha-lipoic Acid in experimental atherosclerosis. J Clin Biochem Nutr 2008;43:88-94. [PubMed: 18818758]

6. Zulkhairi A, Zaiton Z, Jamaluddin M, et al. Alpha lipoic acid possess dual antioxidant and lipid lowering properties in atherosclerotic-induced New Zealand White rabbit. Biomed Pharmacother 2008;62:716-722. [PubMed: 18538528]

7. Çakatay U, Kayali R, Sivas A, Tekeli F. Prooxidant activities of $\alpha$-lipoic acid on oxidative protein damage in the aging rat heart muscle. Arch Gerontol Geriatr 2005;40:231-240. [PubMed: 15814157]

8. Shih JC. Atherosclerosis in Japanese quail and the effect of lipoic acid. Fed Proc 1983;42:24942497. [PubMed: 6404656]

9. Yi X, Maeda N. alpha-Lipoic acid prevents the increase in atherosclerosis induced by diabetes in apolipoprotein E-deficient mice fed high-fat/low-cholesterol diet. Diabetes 2006;55:2238-2244. [PubMed: 16873686]

10. Angelucci L, Mascitelli-Coriandoli E. Anticholesterol activity of alpha-lipoic acid. Nature 1958;181:911-912. [PubMed: 13526725]

11. Yi X, Maeda N. Endogenous production of lipoic acid is essential for mouse development. Mol Cell Biol 2005;25:8387-8392. [PubMed: 16135825]

12. Yi X, Kim K, Yuan W, Xu L, Kim HS, Homeister JW, Key NS, Maeda N. Mice with heterozygous deficiency of lipoic acid synthase have an increased sensitivity to lipopolysaccharide-induced tissue injury. J.Leukoc Biol 2009;85(1):146-153. [PubMed: 18845616]

13. Maeda N, Johnson L, Kim S, Hagaman J, Friedman M, Reddick R. Anatomical differences and atherosclerosis in apolipoprotein E-deficient mice with 129/SvEv and C57BL/6 genetic backgrounds. Atherosclerosis 2007;195(1):75-82. [PubMed: 17275002]

14. Zhang SH, Reddick RL, Burkey B, Maeda N. Diet-induced atherosclerosis in mice heterozygous and homozygous for apolipoprotein E gene disruption. J Clin Invest 1994;94:937-945. [PubMed: 8083379]

15. Valero E, Garcia-Carmona F. Optimizing enzymatic cycling assays: spectrophotometric determination of low levels of pyruvate and L-lactate. Anal Biochem 1996;239:47-52. [PubMed: 8660624]

16. Yi X, Maeda N. alpha-Lipoic acid prevents the increase in atherosclerosis induced by diabetes in apolipoprotein E-deficient mice fed high-fat/low-cholesterol diet. Diabetes 2006;55(8):2238-2244. [PubMed: 16873686]

17. Schummer CM, Werner U, Tennagels N, et al. Dysregulated pyruvate dehydrogenase complex in Zucker diabetic fatty rats. Am J Physiol Endocrinol Metab 2008;294:E88-E96. [PubMed: 17957038] 
18. Ohara Y, Peterson TE, Harrison DG. Hypercholesterolemia increases endothelial superoxide anion production. J Clin Invest 1993;91:2546-2551. [PubMed: 8390482]

19. Packer L, Witt EH, Tritschler HJ. alpha-Lipoic acid as a biological antioxidant. Free Radic Biol Med 1995;19:227-250. [PubMed: 7649494]

20. t Hoen PA, Van der Lans CA, Van Eck M, Bijsterbosch MK, Van Berkel TJ, Twisk J. Aorta of ApoE-deficient mice responds to atherogenic stimuli by a prelesional increase and subsequent decrease in the expression of antioxidant enzymes. Circ Res 2003;93:262-269. [PubMed: 12829615]

21. Steinberg D. Atherogenesis in perspective: hypercholesterolemia and inflammation as partners in crime. Nat Med 2002;8:1211-1217. [PubMed: 12411947]

22. Kim MS, Park JY, Namkoong C, et al. Anti-obesity effects of alpha-lipoic acid mediated by suppression of hypothalamic AMP-activated protein kinase. Nat Med 2004;10:727-733. [PubMed: 15195087]

23. Martin E, Rosenthal RE, Fiskum G. Pyruvate dehydrogenase complex: metabolic link to ischemic brain injury and target of oxidative stress. J Neurosci Res 2005;79:240-247. [PubMed: 15562436]

24. Raghavamenon A, Garelnabi M, Babu S, Aldrich A, Litvinov D, Parthasarathy S. Alphatocopherol is ineffective in preventing the decomposition of preformed lipid peroxides and may promote the accumulation of toxic aldehydes: a potential explanation for the failure of antioxidants to affect human atherosclerosis. Antioxid Redox Signal 2009;11(6):1237-1248. [PubMed: 19186999]

25. Miller AA, De Silva TM, Jackman KA, Sobey CG. Effect of gender and sex hormones on vascular oxidative stress. Clin Exp Pharmacol Physiol 2007;34:1037-1043. [PubMed: 17714091] 

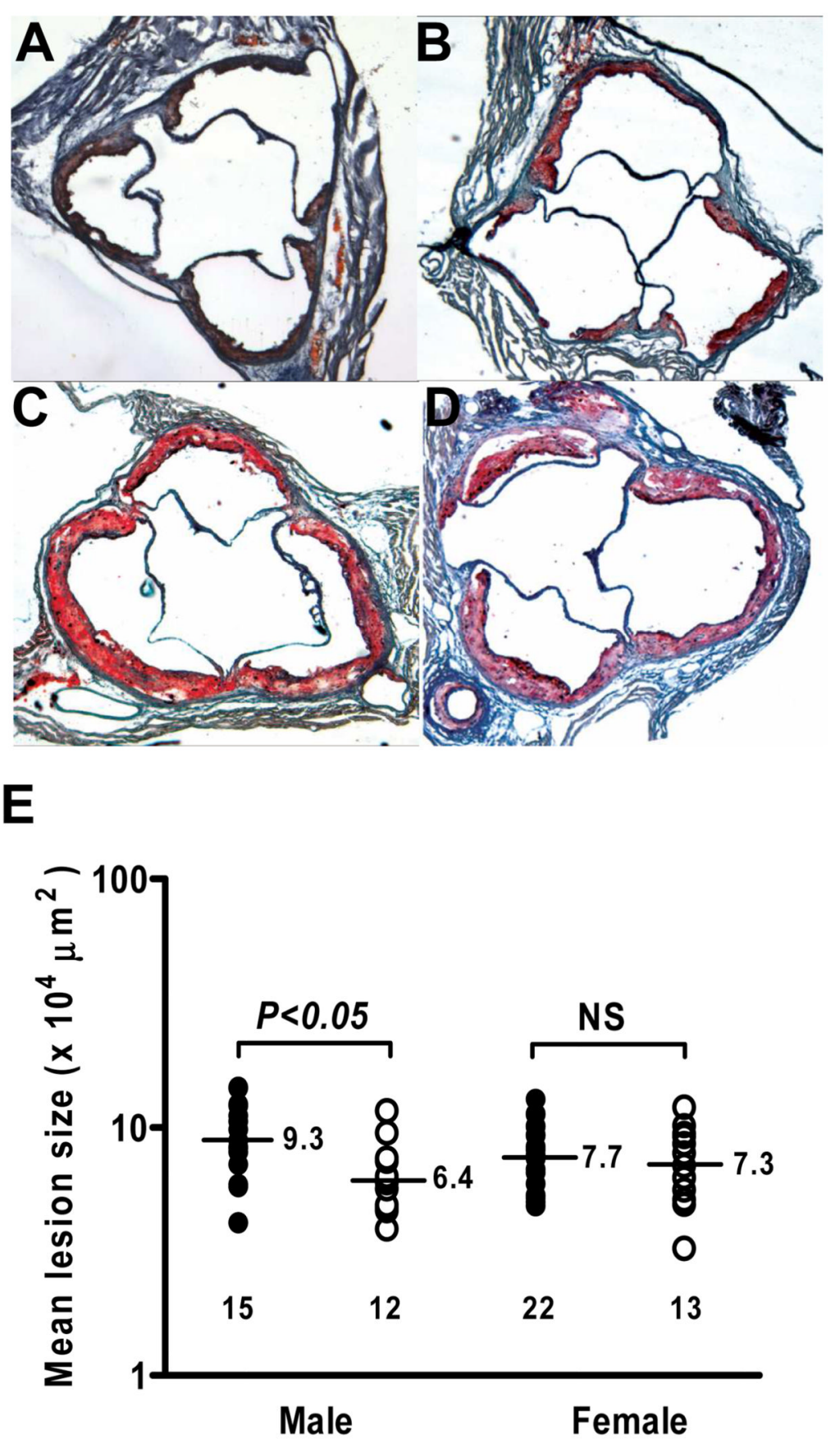

Figure 1.

Representative light photomicrographs of aortic roots of $\mathrm{Lias}^{+/-}$(A and C) and $\mathrm{Lias}^{+/+}$mice (B and D) on an ApoE ${ }^{-/-}$background. Sections are stained with Sudan IV and counterstained with hematoxylin. (E) Atherosclerotic plaque sizes at the aortic roots of 6month-old male and female $\mathrm{Lias}^{+/-} \mathrm{ApoE}^{-/-}$mice (filled circles) and $\mathrm{Lias}^{+/+} \mathrm{ApoE}^{-/-}$mice (open circles). Each dot represents the mean lesion size of 4 sections in each mouse in log scale. Horizontal bars with numbers indicate antilog of log means. The numbers of the dots indicate animal numbers per group. 

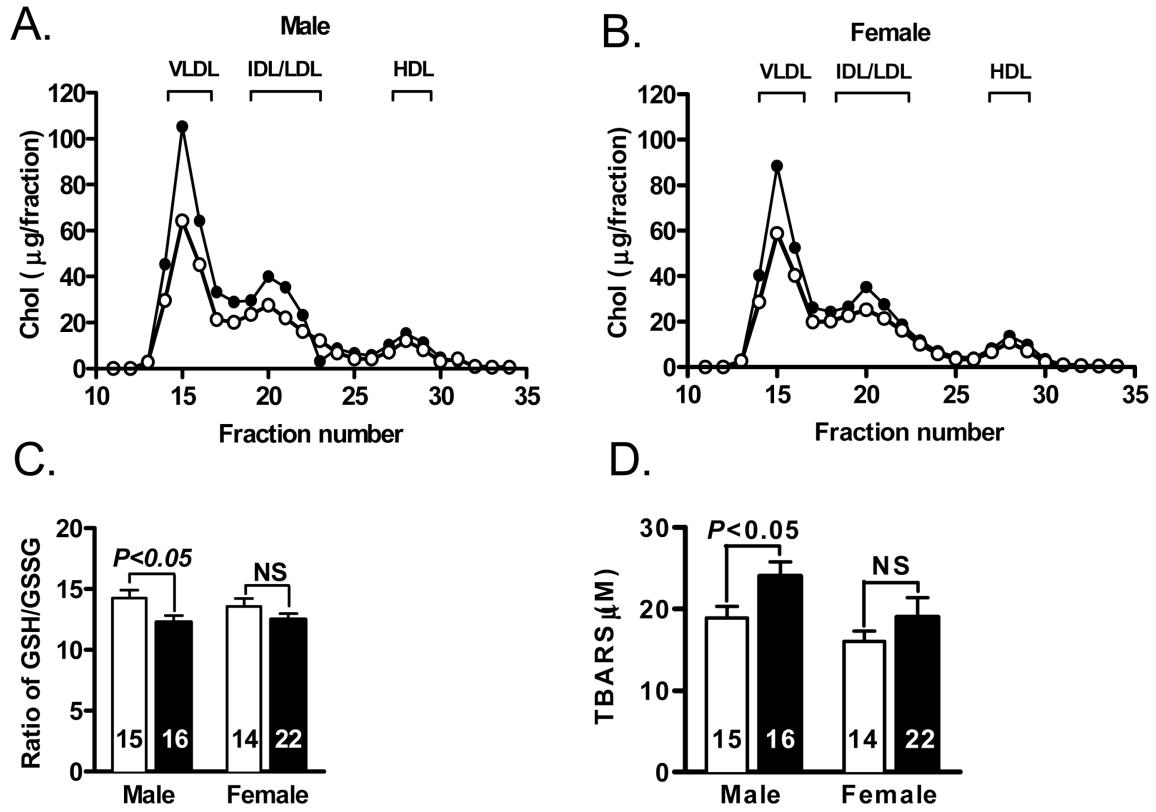

E.

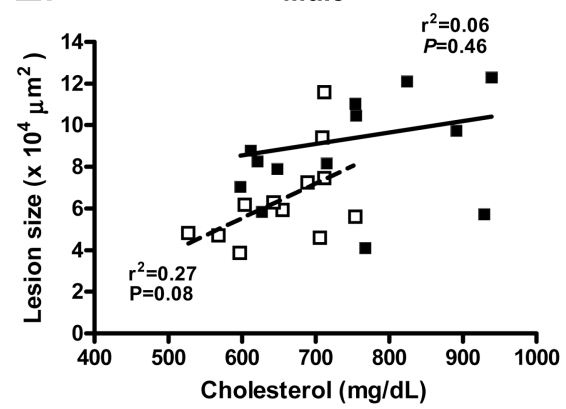

G.

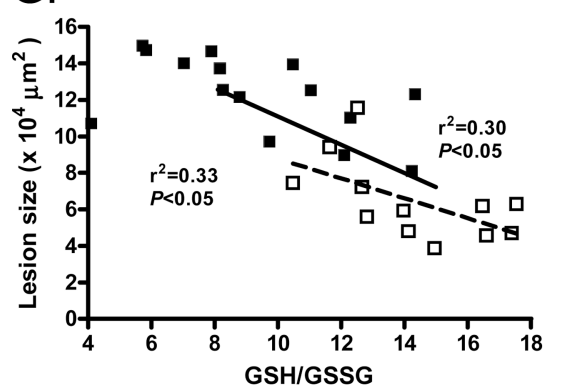

F.

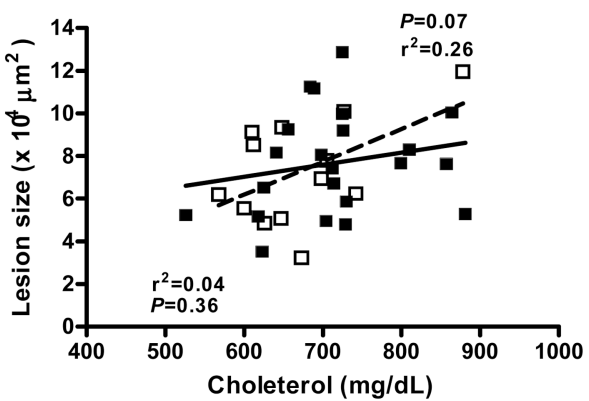

$\mathrm{H}$.

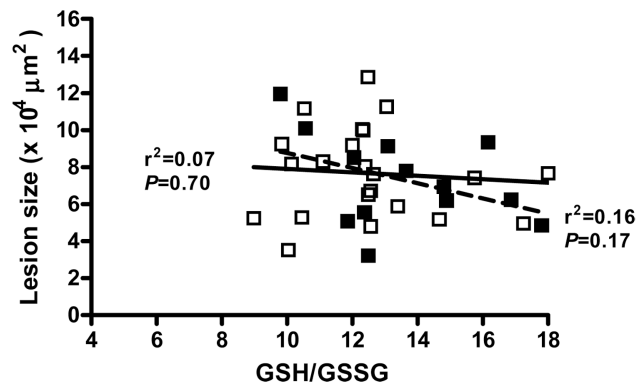

Figure 2.

(A and B) Plasma lipoprotein profiles separated by fast performance liquid chromatography (FPLC) in $\mathrm{Lias}^{+/-} \mathrm{ApoE}^{-/-}$mice (black dots) and $\mathrm{Lias}^{+/+} \mathrm{ApoE}^{-/-}$mice (white dots). Cholesterol was determined by measurement of an aliquot of each fraction. (C and D) General oxidative stress markers in $\mathrm{Lias}^{+/-} \mathrm{ApoE}^{-/-}$mice (black bars) and $\mathrm{Lias}^{+/+} \mathrm{ApoE}^{-/-}$ mice (white bars) at 6 months of age. (C) Ratio of erythrocyte reduced glutathione (GSH)/ oxidized glutathione (GSSG). (D) Plasma thiobarbituric acid reactive substances (TBARS). The numbers inside bars indicate number of animals. Results are expressed as mean \pm SEM. (E, F, G, and H) Simple linear regression analysis between plasma cholesterol and lesion 
size of aortic roots (E and F), and between ratio of GSH/GSSG in erythrocyte and lesion size $(\mathrm{G}$ and $\mathrm{H})$ in $\mathrm{Lias}^{+/-} \mathrm{ApoE}^{-1-}$ (black squares) and $\mathrm{Lias}^{+/+} \mathrm{ApoE}^{-/-}$mice (white squares). 
A.

C.
B.

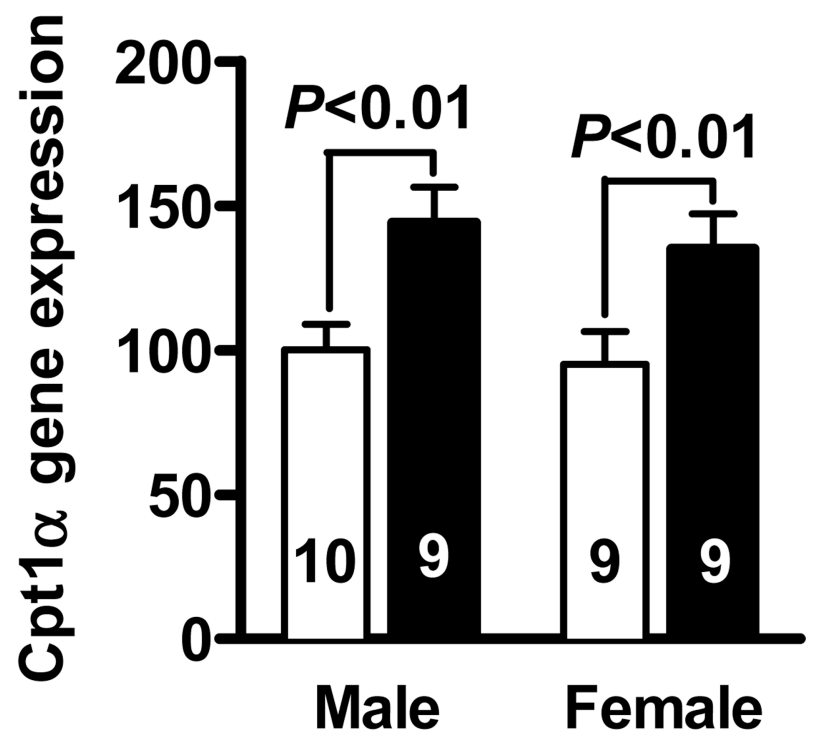

D.
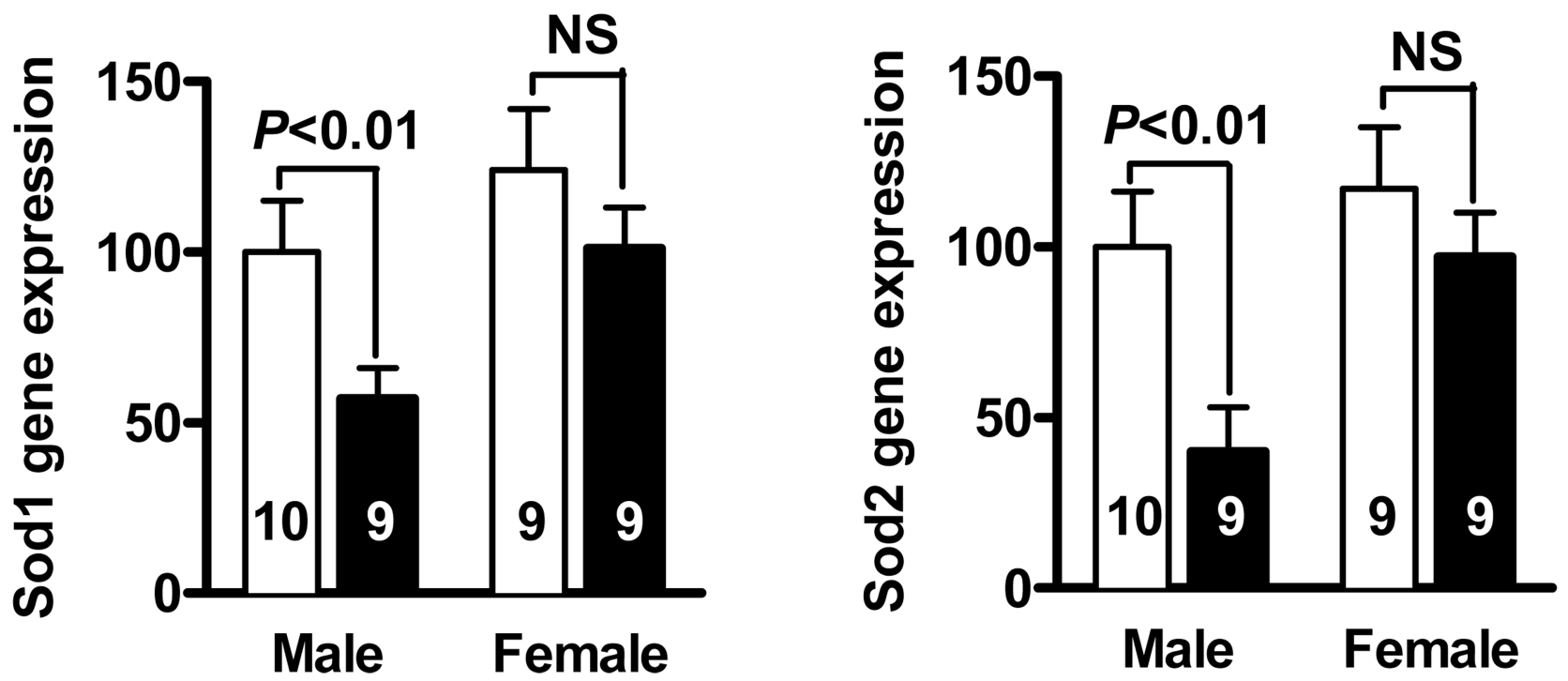

Figure 3.

(A) Activity of pyruvate dehydrogenase complex in the livers of $\mathrm{Lias}^{+/-} \mathrm{ApoE}^{-/-}$and Lias $^{+/+} A \mathrm{poE}^{-/-}$mice at 6 months of age. (B) Gene expression of carnitine palmitoyl transferase-1 $\alpha$ in liver. (C and D) Gene expression of Sod1 (C) and Sod2 (D) in aorta. mRNA levels are expressed relative to the mean levels of the mRNA in the male Lias $^{+/+} \mathrm{ApoE}^{-/-}$as $100 \%$. Results are expressed as mean \pm SEM. White bars represent Lias $^{+/-}$Apo $E^{-/-}$mice and black bars stand for Lias $^{+/+} A p o E^{-/-}$mice. Numbers inside bars indicate number of animals. 
